\title{
Effect of an Enzyme Additive on Ensilage Losses of Plant Cell Wall in Italian Ryegrass
}

\author{
Osamu KAWAMURA, Kiichi FUKUYAMA and Mitsuhiro NIIMI \\ Faculty of Agriculture, Miyazaki University, Miyazaki-shi 889-2192, Japan
}

(Received August 29, 2000 ; Accepted December 6, 2000)

\begin{abstract}
The effects of an additive containing cell wall degrading enzyme on the ensilage losses were estimated under a farm condition. At ensiling Italian ryegrass with and without the additive, the nylon-net bags containing grasses were placed into each of the silage bulks. The bags were retrieved when the silages were unloaded, and their contents were subjected to the chemical analyses, in vitro digestion with rumen microbes and microscopic observation. Enzyme treatment improved the silage fermentation. The ensilage loss of cell wall components was highest in hemicellulose. In hemicellulosic monosaccharides, the loss of xylose was lowest, followed by uronic acids, arabinose, galactose and glucose. The losses in treated silage were significantly higher than the control silage in almost all the cell wall components. The losses of digestible-dry matter (DM) and digestible-neutral detergent fiber (NDF) in vitro were also significantly higher in the treated silage. The selective degradations of the readily digestible plant tissues (e.g. mesophyll and pith parenchyma) were observed in the treated silage.
\end{abstract}

Animal Science Journal 72 (2) : 134-138, 2001

Key words : Cell wall components, Ensilage losses, Enzyme additive, Hemicellulosic monosaccharides, Plant tissues

It has been considered that the cell wall degrading enzymes as silage additives have a dual action in the silo; firstly, increasing the supply of fermentable sugars and, secondly, improving the digestibility of silage by partial hydrolysis of the cell wall ${ }^{15)}$. Many researchers have confirmed that the enzyme applications lead to good silage fermentation and preservation, however, they have different opinions on the effects of the enzyme on the digestibility $2,5-8,13-15,18-21$ ). In this study, the losses of plant cell wall during ensilage was examined using an enzyme under a practical farm condition in order to clarify the enzyme's effects on digestibility. However, it was difficult to determine the ensilage losses using a number of practical silos. Therefore, the experiment was conducted with an assumption that the material in net-bags placed in the practical silage bulk was fermented under the same condition as the material in the prac- tical silo.

\section{Materials and Methods}

Italian ryegrass (Lolium multiflorum Lam.) was harvested at the heading stage on 14 May 1991, using a forage harvester in the Experimental Farm of Miyazaki University. Eight tons each of the Italian ryegrass were ensiled in trench silos $(1.5 \times 1.5 \times 5.0 \mathrm{~m})$ with or without the enzyme additive (trade name; Clampzyme, contained cellulase, hemicellulase and glucose oxidase derived from Trichoderma sp.) at the recommended application level $\left(0.1 l \mathrm{t}^{-1}\right)$. The storage period was 127 days. Ensilage losses were measured by the bag method. That is, at the ensiling, the nylon-net bags $(60 \times 35 \mathrm{~cm}, 2 \mathrm{~mm}$ mesh) containing 1 $\mathrm{kg}$ of the raw material with or without the additive, were placed in the middle of each silage bulk. When the silage was unloaded, three and four bags were

Corresponding : Osamu KAWAMURA (fax : +81 (0) 985-58-7259, e-mail : kawamura@cc.miyazaki-u.ac.jp) 
Ensilage Losses with Enzyme Treatment

Table 1. Fermentation characteristics of silages

\begin{tabular}{lrrr}
\hline \hline & $\begin{array}{c}\text { Untreated } \\
\text { silage }(\mathrm{n}=7)\end{array}$ & $\begin{array}{c}\text { Treated } \\
\text { silage }(\mathrm{n}=7)\end{array}$ & $\begin{array}{c}\text { Significance } \\
\text { of difference }\end{array}$ \\
\hline Dry matter $\left(\mathrm{g} \mathrm{kg}^{-1}\right)$ & $179( \pm 7.20)$ & $188( \pm 13.54)$ & $\mathrm{NS}$ \\
$\mathrm{pH}$ & $4.02( \pm 0.10)$ & $3.88( \pm 0.10)$ & $*$ \\
Composition of dry matter $\left(\mathrm{g} \mathrm{kg}^{-1}\right)$ & & & \\
$\quad$ Lactic acid & $75.8( \pm 10.35)$ & $68.9( \pm 10.41)$ & $\mathrm{NS}$ \\
$\quad$ Acetic acid & $20.6( \pm 4.90)$ & $29.4( \pm 8.56)$ & $*$ \\
$\quad$ Propionic acid & $4.42( \pm 0.53)$ & $5.96( \pm 1.66)$ & $* *$ \\
$\quad$ Total butyric acid & $13.2( \pm 7.33)$ & $2.3( \pm 1.59)$ & $* *$ \\
$\quad$ Total valeric acid & $2.72( \pm 0.91)$ & $1.22( \pm 1.52)$ & $*$ \\
Ammonia nitrogen/Total nitrogen $(\%)$ & $11.4( \pm 1.05)$ & $8.9( \pm 1.22)$ & $* *$ \\
\hline
\end{tabular}

$( \pm)$ : Standard deviation. Significance of difference : NS ; not significant, ${ }^{*} ; \mathbf{P}<0.05,{ }^{*} ; \mathbf{P}<0.01$.

Table 2. Recovery percentage of raw material from silages

\begin{tabular}{lccc}
\hline \hline & $\begin{array}{c}\text { Untreated } \\
\text { silage }(\mathrm{n}=3)\end{array}$ & $\begin{array}{c}\text { Treated } \\
\text { silage }(\mathrm{n}=4)\end{array}$ & $\begin{array}{c}\text { Significance } \\
\text { of difference }\end{array}$ \\
\hline Dry matter & $80.3( \pm 1.3)$ & $75.8( \pm 4.5)$ & $\mathrm{NS}$ \\
NDF & $85.7( \pm 5.0)$ & $80.1( \pm 1.8)$ & $\mathrm{NS}$ \\
Cellulose & $92.1( \pm 5.1)$ & $78.8( \pm 1.6)$ & $* *$ \\
Hemicellulose & $78.2( \pm 3.5)$ & $68.6( \pm 2.6)$ & $*$ \\
$\quad$ Arabinose & $70.7( \pm 2.6)$ & $61.3( \pm 2.8)$ & $*$ \\
$\quad$ Xylose & $85.6( \pm 3.5)$ & $75.9( \pm 3.4)$ & $*$ \\
$\quad$ Galactose & $57.0( \pm 3.7)$ & $50.8( \pm 2.4)$ & $*$ \\
$\quad$ Glucose & $47.3( \pm 3.4)$ & $35.9( \pm 1.3)$ & $*$ \\
Uronic acids & $77.3( \pm 4.3)$ & $68.2( \pm 1.6)$ & $*$ \\
Digestibnin & $89.6( \pm 6.9)$ & $96.3( \pm 4.5)$ & NS dry matter in vitro \\
Digestible NDF in vitro & $78.8( \pm 0.8)$ & $70.3( \pm 4.2)$ & $*$ \\
\hline
\end{tabular}

$( \pm)$ : Standard deviation. Significance of difference : NS ; not significant, ${ }^{*} ; \mathrm{P}<0.05,{ }^{* *} ; \mathrm{P}<0.01$.

retrieved from one untreated and one treated silo, respectively, and the contents were weighed again and the dry matter (DM) was determined by toluene distillation. In the statistical analysis, each bag was regarded as each silo for convenience' sake. The raw material and the silages in and around the bags were subjected to chemical analyses. Neutral detergent fiber (NDF), acid detergent fiber (ADF), acid detergent (AD)-lignin and in vitro digestibility with rumen microbes were determined by the method of Goering and Van Soest ${ }^{4)}$. For hemicellulose determination, the residues treated with hot water, alcohol and acetone were hydrolyzed by $2 \mathrm{~N}$ sulfuric acid. The hydrolysates were subjected to the determinations for neutral sugars and uronic acids by a gas liquid chromatography $^{3)}$ and a colorimetry ${ }^{1)}$, respectively. The fermentation characteristics of silage were measured on the water extract by the method described in our previous paper ${ }^{17)}$. The plant tissues in the nylonnet bags were observed through a light microscope ${ }^{12\rangle}$. 

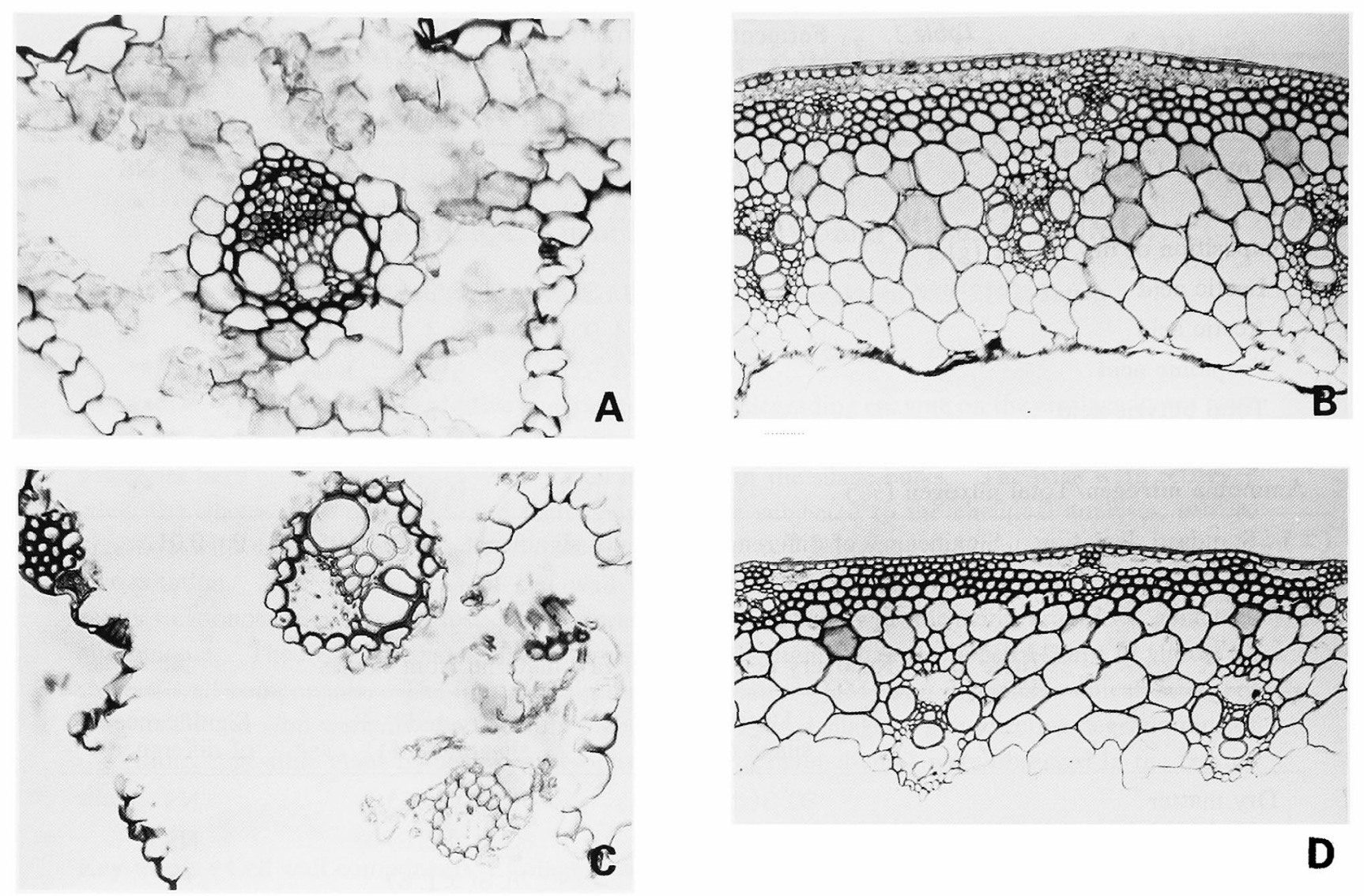

Fig. 1. Transections of Italian ryegrass ensiled with and without the enzyme additive.

A ; Leaf blade in the untreated silage, B ; Stem in the untreated silage, C ; Leaf blade in the treated silage, D ; Stem in the treated silage. A selective degradation of the mesophyll, the pith parenchyma and the phloem was observed in the treated silage.

\section{Results and Discussion}

Enzyme treatment improved the silage fermentation. The $\mathrm{pH}$, butyric acid and ammonia nitrogen concentrations were significantly lower in the treated silage than in the control (untreated) silage (Table 1).

Table 2 shows the recoveries of raw material from silages. The recovery of dry matter of raw material was $80 \%$ in the control and $76 \%$ in the treated silage. These values were comparable to the results obtained previously ${ }^{15)}$. Of the cell wall components, hemicellulose losses were highest in both the silages. The loss of hemicellulosic monosaccharides was lowest in xylose, followed by uronic acids, arabinose and galactose. The loss of glucose was highest. These results agreed with the data previously reported $^{6,7,14.16,17)}$. We have already observed the di- gestibility of hemicellulosic monosaccharides in sheep and in heifer, where digestibility of xylose was lowest and that of glucose was highest ${ }^{9-11)}$. Therefore, it appears that the more digestible in the rumen, the greater loss in silo.

The losses of all the cell wall components except NDF and AD-lignin were significantly higher in the treated silage than in the control silage. The losses of the digestible DM and digestible NDF in vitro were also significantly higher in the treated silage. This may indicate that the use of enzyme additive decreases the yield of nutrients for ruminant production. However, these significant differences between the two silages do not directly suggest the treatment effect under the practical condition because of the inadequate experimental design with the limited practical silo in this experiment. 
In the control silage, the recoveries of digestible $\mathrm{DM}$ and digestible NDF in vitro were not largely different from the recoveries of DM and NDF, respectively ( $79 \%$ vs. $80 \%, 85 \%$ vs. $86 \%)$. However, in the treated silage, the recoveries of digestible parts were much lower (70\% vs. $76 \%, 70 \%$ vs. $80 \%$ ). These results suggest that the enzyme might have selectively degraded the readily digestible cell wall by rumen microbes. This was supported by the microscopic observations (Fig. 1), where the mesophyll of leaf blade, pith parenchyma of stem and phloem, which were not lignified and were readily digestible in the rumen ${ }^{12)}$, were selectively degraded in the treated silage. This may be related to the higher amount of effluent loss from enzyme-treated silages ${ }^{5,6)}$ because mesophyll and parenchyma are rich in cell contents ${ }^{12}$.

In conclusion, the use of cell wall degrading enzyme might improve the silage fermentation, but increase ensilage losses, especially, of the readily digestible part of plant cell wall by ruminant. It would be better to use the other methods (e.g. wilting) for the improvement of fermentation quality in the silage making from high moisture forage like Italian ryegrass used in this experiment.

\section{References}

1) Blumenkranz N, Asboe-Hansen G. New method for quantitative detcrmination of uronic acids. Analytical Biochemistry, 54 : 484-489. 1973.

2) Chamberlain DG, Robertoson $S$. The effects of the addition of various enzyme mixtures on the fermentation of perennial ryegrass silage and on its nutritional value for milk production in dairy cows. Animal Feed Science and Technology, 37 : 257-264. 1992.

3) Englyst $\mathbf{H N}$, Cummings JH. Improved method for measurement of dietary fiber as non-starch polysaccharides in plant foods. Journal of the Association of Official Analytical Chemists, $71: 808-814.1988$.

4) Goering HK, Van Soest PJ. Forage Fiber Analyses. Agriculture Handbook 379. USDA. Washington. 1970.

5) Jaakkola $S$, Huhtanen $P$, Hissa $K$. The effect of cell wall degrading enzymes or formic acid on fermentation quality and on digestion of grass silage by cattle. Grass and Forage Science, 46 : 75-87. 1991.

6) Jacobs JL, McAllan AB. Enzymes as silage additives.
1. Silage quality, digestion, digestibility and performance in growing cattle. Grass and Forage Science, $46: 63-73.1991$.

7) Jacobs JL, Cook JE, McAllan AB. Enzymes as silage additives. 2. The effect of grass dry matter content on silage quality and performance in sheep. Grass and Forage Science, 46 : 191-199. 1991.

8) Jakhmola RC, Weddell JR., Greenhalgh JFD. Ensiling grass with straw. III. Effect of urea and enzyme aditives on the feeding values of grass and straw silages. Animal Feed Science and Technology, 41 : 87-101. 1993.

9) Kawamura O, Tanaka S, Miaki T. The digestibility of cell wall components by sheep of some tropical grasses in Japan. Herbivore Nutrition Research, Australian Society of Animal Production, Brisbane, Australia. pp. 15-16. 1987.

10) Kawamura O, Tanaka S, Miaki $T$, Shinkai K. Digestibility of hemicellulose monosaccharides in some sorghum silage. Bulletin of the Faculty of Agriculture, Miyazaki University, 39:63-65. 1992.

11) Kawamura O, Tanaka S, Miaki T, Shinkai K. Comparison of Digestibility of sorghum silage by sheep and by heifers with special reference to the hemicellulose mono-saccharides. Proceedings of the XVII International Grassiand Congress, 937-938. 1993.

12) Kawamura $O$. Histochemical studies on forage digestion in the rumen. -a Review-Grassland Science, 43 : 171-178. 1997

13) Kung L Jr, Carmean BR, Tung, RS. Microbial inoculation or cellulase enzyme treatment of barley and vetch silage harbested at three maturities. Journal of Dairy Science, 73 : 1034-1311. 1990.

14) Matsuoka S, Branda LN, Fujita H. Breakdown of structural carbohydrates during the ensiling process of grasses treated with lactobacillus inoculant and cellulase preparation and the subsequent effects on their in vitro digestibilities. Animal Science and Technology, 68: 661-667. 1997.

15) McDonald $P$, Henderson AR, Heron SJE. The biochemistry of silage. 2 nd ed. 184-236. Chalcombe Publications. Marlow. 1991.

16) Morrison IM. Changes in the cell wall components of laboratory silages and the effect of various additives on these changes. Journal of Agricultural Science, Cambridge, 93 : 581-586. 1979.

17) Niimi M, Kawamura $O$. Degradation of cell wall constituents of Guineagrasss (Panicum maximum Jacq.) during ensiling. Grassland Science, $43: 413$ 417. 1998. 


\section{KAWAMURA, FUKUYAMA and NIIMI}

18) Selmer-Olsen I. Enzymes as silage additives for grassclover mixtures. Grass and Forage Science, 49 : 305315. 1994.

19) Tengerdy RP, Weinberg ZG, Szakacs G, Wu M, Linden JC, Henk LL, Johnson DE. Ensiling alfalfa with additives of lactic acid bacteria and enzymes. Journal of Science Food and Agriculture, 55 : 215228. 1991.
20) Weinberg ZG, Ashbell G, Azrieli A, Brukental I. Ensiling peas, ryegrass and wheat with additives of lactic acid bacteria (LAB) and cell wall degrading enzymes. Grass and Forage Science, 48 : 70-78. 1993.

21) Zhu $Y$, Nishino N, Uchida $S$. Fermentation of rhodesgrass silages with or without wilting and added cell wall degrading enzymes. Grassland Science, $46: 22-27.2000$. 